\title{
Reviews
}

\section{Securing Courtroom Decorum}

\author{
Geoffrey G. Hazard, Jr.†
}

Report and Recommendations on Disruption of the Judicial Process. By American College of Trial Lawyers, Committee on Disruption of the Judicial Process. 1970. Pp. 23. Standards Relating to the Function of a Trial Judge. By American Bar Association, Advisory Committee on the Judge's Function. Preliminary Report: August, 1970. Pp. 18.

The spectacle of United States $v$. Dellinger, ${ }^{1}$ has impelled two distinguished organizations of the legal profession to promulgate rules designed to secure courtroom decorum. In July, 1970, the American College of Trial Lawyers, through a special Committee on Disruption of the Judicial Process, published its Report and Recommendations. In January, 1971, the American Bar Association received a report on Standards Relating to the Function of a Trial Judge from its Advisory Committee on the Judge's Function, a constituent of the ABA's Project on Standards for Criminal Justice.

Both reports aim explicitly at clarifying the standards of behavior that are expected in a courtroom and the disciplinary procedure and sanctions to be employed when those standards are violated. Both reports also aim implicitly at inhibiting such violations. Many of their proposals are identical or substantially similar. There are, however, significant differences in their approaches to coping with deliberately deviant behavior in the courtroom. In the latter respect the Reports echo larger and louder debates which have been going on for some time now and which will have to come closer to conclusion before the problem of forensic misconduct can be satisfactorily resolved. In the meantime, the proposals advanced in the Reports provide an invitation for the bench and bar to ponder what may be achieved by more carefully considered rules on the subject.

$\dagger$ Visiting Professor of Law, Yale University; Professor of Law, University of Chicago.

1. No. 69 CR-180 (N.D. III., jury verdict rendered Fcb. 14, 1970). The codcfendants were: David Dellinger, Rennard Davis, Thomas Hayden, Abbott Hoffman, Jerry Rubin, Lee Weiner, John Froines, and Bobby Seale. 


\section{The Control of Trial Participants}

The Report of the Committee on Disruption of the Judicial Process of the American College of Trial Lawyers (hereinafter the "Trial Lawyers Report") is in essence an address to lawyers concerning what a trial ought to be. It begins by describing the purpose of trials ("equal justice for all') ${ }^{2}$ and the atmosphere that ought to prevail in them ("dignity, decorum and courtesy"). ${ }^{3}$ It describes the obligations of the lawyer ("to represent every client courageously . . . according to law and the ... canons of the legal profession") 4 and the judge ("to treat every lawyer with ... courtesy and respect ... and to avoid becoming personally involved").5 It then postulates the disciplinary authority of the judge ("[a] judge has power to punish summarily for contempt any lawyer who in his presence willfully contributes to disorder or disruption in the courtroom" $)^{6}$ and the sanctions that he may impose. These recommended sanctions include: "fine or imprisonment [for not more than six months] . . . termination of the lawyer's right to continue as counsel in the case ... suspension ... of his right to appear in [other cases]," and "continuance ... or, if that is not practicable . . . a mis" trial.""8

In connection with the use of sanctions, the Trial Lawyers Report suggests that the trial judge should give warning of what he expects, that appellate review of lawyer contempts should be expedited, ${ }^{10}$ and that proceedings for suspension or disbarment should be initiated against a lawyer whose conviction of contempt is sustained. ${ }^{11}$ It is also proposed that pro hac vice admissions be subject to special scrutiny and, in appropriate cases, conditioned upon associating local co-counsel..$^{12}$

2. American College of Trial Lawyers, Report and Recommendations on Dis. RUPTION OF THE JUdicial Process, Principle I (1970) [hereinafter cited as ThAL Lawyers REPORT].

3. Id., Principle II.

4. Id., Principle III.

5. Id., Principle IV.

6. Id., Principle V.

7. Id., Principle VI. The Trial Lawyers Report concedes that summary imposition of suspension from the bar "may seem to some a wide departure from existing practicc." But the commentary argues that since courts presently supervise admission to the bar, and have "ultimate control" over the right to practice, there should be no objection to the courts exercising "direct control" over the right to practice in certain circumstances. The due process problems and dangers of abuse are not addressed by the Trial Lawyero Report.

8. Id., Principle VIr.

9. See id., Principle VIII.

10. See id., Principle IX.

11. See id., Principle XI (which also recommends expedited procedures for consider. ing complaints of judicial misbehavior).

12. See id., Principle X. 
The focus on lawyer decorum is emphasized by a concluding notation that the Report does not undertake to deal with the problem of disruptive behavior by litigants or spectators, except indirectly through the obligation of the lawyer "to prevent [his client], so far as lies within the lawyer's power, from creating disorder or disruption in the courtroom."13

While the Trial Lawyers Report is thus addressed primarily to lawyers, secondarily to judges and only incidentally to the other participants in the trial, the Report of the Advisory Committee on the Judge's Function (hereinafter the "ABA Report") is concerned with the roles of all the trial participants from the perspective of the judge. The ABA Report provides that "the trial judge has the responsibility for safeguarding both the rights of the accused and the interests of the public,"1s that the judge "should prescribe and make known the ground rules relating to conduct ... in the courtroom,"15 and that he "should be the exemplar of dignity and impartiality." 10 At the same time, it provides that "no one has the right to disrupt or prevent the orderly course of the trial, ${ }^{17}$ specifically including the defendant, ${ }^{18}$ counsel, ${ }^{10}$ and spectators, the latter being reminded that "the right of the defendant to a public trial does not give particular members of the general public or of the news media a right to enter the courtroom or to remain there." ${ }^{20}$ With respect to the enforcement of the norms of courtroom conduct, the ABA Report not only calls for advance statement of ground rules but encourages the use of warnings and requires them regarding conduct not obviously and willfully contemptuous. ${ }^{21}$ It also encourages the use of exclusion rather than contempt as an initial sanction where feasible.22

On the procedures for contempt, the ABA Report affirms the trial judge's power of summary punishment, ${ }^{23}$ but with the admonition that the judge "should consider the advisability of deferring adjudications

19. Id., Principle III.

14. Advisory Committee on the Judge's Function (American Bar Associztion), Slandards Relating to the Function of a Trial Judge (preliminary draft) Standard A.1 (1970) [hereinafter cited as ABA REPORT].

15. Id., Standard A.4.

16. Id., Standard B.I.

17. Id., Standard A.2.

18. Id., Standard C.l.

19. Id., Standard D.1.

20. Id., Standard E.1.

21. Id., Standards F.2, F.3(b), F.2(b).

22. See id., Standards A.3 "the judge ... should ordinarily impose the least severe sanction appropriate"); C.1 ("removal is preferable to gagging or shadiling the disruptive defendant $\left.t^{\prime \prime}\right)$.

23. See id., Standard F.I. 
of contempt ... until after the trial." ${ }^{24}$ Moreover, exercise of the contempt power is made subject to the requirements that the cited person be given notice of the charges and "at least a summary opportunity to adduce evidence and argument relevant to guilt or punishment." ${ }^{\text {"Is }}$ It also provides that an alleged contempt be determined by another judge where the conduct of the trial judge "was so integrated with the alleged contempt that he contributed to it or was otherwise involved, or his objectivity can for any reason plausibly be questioned."20

The ABA Report, like the Trial Lawyers Report, contains special provisions concerning admission of lawyers pro hac vice and acceleration of appellate review of lawyer contempts. Unlike the Trial Lawyers Report, and emphasizing a difference in frame of reference, the $A B A$ Report speaks only incidentally of post-contempt suspension or disbarment of a lawyer. ${ }^{27}$

As a result of their differences in orientation, the two Reports cover overlapping but somewhat different subject matter. ${ }^{28}$ On the aspects of forensic misconduct that are of greatest practical importance and difficulty, however, the Reports cover common ground. These are the intertwined problems of judicial intemperance and lawyer misconduct. These problems are difficult to solve simply because the possible remedies and sanctions by which to control them are so limited as compared to those which may be invoked against a litigant or spectator. A disruptive spectator may simply be excluded from the trial. ${ }^{20}$ Members of the news media can be excluded if their presence intrudes on calm and orderly procedure. ${ }^{30} \mathrm{~A}$ comparable principle applies to those whose right of attendance derives from their affinity with the defendant-spouse, relatives, priest, etc. ${ }^{31}$ As to litigants, Illinois $v$. Allen $^{32}$ has now made

\footnotetext{
24. See id., Standard F.3(a).

25. Id., Standard F.4.

26. Id., Standard F.5.

27. Id., Standard F.6.

28. The Trial Lawyers Report alludes to the fact that the advocate's courtroom rcpre. sentation of his client is a phase of a responsibility that has begun outside of court, while the ABA Report refers to the advocate's function only as of the beginning of trial. The Trial Lawyers Report requires the lawyer to exercise a restraining influence on his client, while the ABA Report proscribes misconduct of lawyer and litigant without reference to accessorial implications. The Trial Lawyers Report presupposes a trial in which the litigant is represented by counsel, while the ABA Report has provisions applicable to a defendant appearing pro se. On the basis of what may be a different attitude toward conservation of trial time, the Trial Lawyers Report admits of the possibility of a continuance as a remedy and a mistrial as a sanction for forensic mis. conduct, while the ABA Report omits explicit reference to either of these devices.

29. See, e.g., 23 C.J.S. Criminal Law $\$ 970$ (1961).

30. See, e.g., Estes v. Texas, 381 U.S. 532 (1965); 23 C.J.S. Criminal Lau' $\$ 969\langle 0)$.

31. See, e.g., 23 C.J.S. Criminal Law \& 970.

32. 397 U.S. 337 (1970).
} 
clear that a defendant's presence at trial is a right that can be denied if he refuses to conform to elemental requirements of courtroom decorum. Accordingly, where a litigant's disturbances obstruct fulfillment of his opportunity to participate, he may be excluded and his trial conducted in absentia. But while in special circumstances bystanders and even litigants can be dispensed with and a trial still be held, the same is not true of the judge nor, in an adversary system, of counsel. In the extraordinary case that would test our definition of a trial, they are the primary participants. ${ }^{33}$

\section{The Proposed Rules}

The proposed rules applicable to judges and lawyers cover four stages: pre-trial measures for anticipating and moderating potential trial disruption; powers and duties in the presentation of the principal case; procedures for making accusations of contempt; and standards for conducting the contempt hearing. In "natural sequence" these stages occur in the order stated: pre-trial, trial, contempt citation, contempt hearing. Yet the relationship between these stages is more than chronological. The courtroom atmosphere and the participants' predispositions in a succeeding stage are established not only by what was lawfully appropriate at a preceding stage, but also by what occurred in fact at that time. The conduct of the participants in any given stage is likewise influenced by their expectations about what will or may occur subsequently. Courtroom events are perceived and interpreted not only in terms of what was, is and is likely to be from an objective point of view, but in terms of the participants' conceptions of what ought to have been and ought to be. The rules of forensic conduct are thus ideas that simultaneously reconstruct the past, order the present and forecast the future of a trial. For the judge and the lawyers these conceptions are especially vivid and complex, combining the letter of text with the glosses of professional experience.

Because the rules governing the professional participants intersect in this way, to analyze them in sequence-any sequence-is in some respects to distort them. Given this salient difficulty, the most satis-

33. The defendant who represents himself would still be subject to the Allen requirements of maintaining elementary decorum, and could be excluded if he, after proper warning, continued to disrupt the trial. In that case the court would presumably endenvor to appoint counsel, even over defendant's objection. Cf. Mayberry v. Pennsylvania, 91 S. Ct. 499, 506 (1971) (concurring opinion); ABA REPorr, Standards C.2, C.3, and C.4. 
factory way to examine the rules is in reverse order, starting with the procedure for determining contempts.

\section{A. Who Adjudicates?}

The central question at the stage of adjudicating a contempt is who shall preside. The ABA Report's proposal is equivocal. It says that the trial judge may ordinarily hear the contempt, but provides for referral where "his conduct was so integrated with the alleged contempt that he contributed to it or was otherwise involved, or his objectivity can for any reason plausibly be questioned." ${ }^{34}$ As applied to misconduct by lawyers, the exception nearly swallows the rule. Lawyers know in general what the forensic rules are and know or quickly intuit how a particular judge inclines to interpret them. Thus, if the judge is fairly consistent in his attitude during the trial, the lawyer can work pretty close to the margin of contempt without going over the line except sporadically. In such circumstances, it is unusual and generally regarded as inappropriate to pursue a citation for contempt. If there is a citation in such a case, the trial judge's objectivity can plausibly be questioned either on the ground that the contempt prosecution is mexe personal retribution or that such a close case requires an indisputably neutral arbiter. On the other hand, where a lawyer's trial conduct has been grossly disruptive, it may have been that the judge's efforts to control the trial were simply ineffectual, which is itself an involvement of a very disturbing kind, or were even provocative, which is also a form of involvement. Putting the matter differently, under the $A B A$ proposal arguments suggest themselves that would render legally infirm any attempt by the trial judge to hear a contempt except in the most clear-cut instances. Those are not the cases that test a code.

The Trial Lawyers Report does not attempt considered analysis of the question of who should preside at the contempt hearing. The position taken is the traditional one that the trial judge should conduct the henring. The Report recognizes that the trial judge may refer the matter to another judge but its commentary disaffirms and even disparages such

34. ABA REPORT, Standard F.5. The Supreme Court has recently given substantial support to this approach to hearing courtroom contempts. In Mayberry v. Pennsylvania, 91 S. Ct. 499 (1971), the Court reversed the contempt sentence of a defendant who represented himself, noting that "[w]here ... [a judge] does not act the instant the contempt is committed, but waits until the end of the trial, on balance, it is generally wise where the marks of the unseemly conduct have left personal stings to ask a fellow judge to take his place." Id. at 504. At the end of its opinion, the Court also stated an apparently broader rule: "Our conclusion is that by reason of the Due Process Clause of the Fourteenth Amendment a defendant in criminal contempt proceedings should be given a public trial before a judge other than the one reviled by the contemnor." Id. at 505. 
a possibility. The principal justification offered for having the trial judge hear the contempt is that otherwise the trial will be delayed or the disorders will continue, or both. It is difficult to see how these consequences are avoided by having the trial judge decide the contempt unless it is also assumed that he do so summarily. It will be suggested below that summary procedure probably does not have the deterrent effect attributed to it, although in the final analysis it is only such an effect that would justify summary procedure.

The Trial Lawyers Report concedes that "some persons are troubled by the thought of a judge acting not only in that capacity [as judge] but also as accuser and prosecutor" and responds by saying that the trial judge has the responsibility to "keep a case moving" and to "keep it under control at all times." 35 The response is true but irrelevant: the police have the duty to keep a crowd moving and to keep it under control, but we do not for that reason give them exclusive authority to punish misconduct at a police line. Perhaps recognizing the weakness of this response, the Trial Lawyers Report goes on to suggest that impartiality in adjudicating the contempt can be secured through appeal:

Impartial, disinterested protection against the abuse of judicial power can and should be provided by appellate review .... An appellate court has power not only to decide whether any contempt was committed, but also whether the sentence imposed was within the bounds of judicial discretion. ${ }^{30}$

This must be one of the few occasions where an association of barristers has argued that a fair appeal procedure is a sufficient corrective for an apparently biased trial procedure. There are other paradoxes in the argument. The assumption that an appeal will be taken contradicts the assumption that summary determination is essential. Treating the trial court contempt conviction as in effect only an indictment returnable in the appellate court denigrates the tribunal whose stature is sought to be enhanced. And what is involved in the reversal of a contempt in such circumstances: that the trial judge was wrong in his instincts for issuing the citation and wrong also in his considered decision to convict at the contempt hearing? A procedural scheme that thus forces choice between a lawyer's career and a judge's reputation is surely more heroic than prudent.

35. Triat Lawyers RePort, Principle $V$, commentary at p. 12.

36. Id., at p. I3. See also Principle IX (Appellate Review). 
Contemplation of these consequences leads one to reconsider the premises. Why shouldn't the traditional view be abandoned and instead the rule adopted that lawyer contempts shall be heard by another judge, if possible one from another locality? Administering such a rule would not entail much additional cost, unless it is supposed that a summary contempt conviction can rest solely on the trial judge's memory of the events at issue-a procedure which would be the ultimate form of trial in camera. ${ }^{37}$ Requiring a contempt hearing to be held by another judge expresses the same principle as the rule which bars a judge from hearing a case in which he has a financial or familial interest, ${ }^{38}$ and recognizes that professional probity is at least as precious to a judge as money or kinship.

What would be lost? If the trial judge was fair and the lawyer intemperate, what clearer vindication of the judge? If the judge was not fair or the lawyer not intemperate, what surer vindication of the lawyer? The adversary method of eliciting facts can be employed before another trial judge but is unavailable in an appellate courtis the adversary method less useful when the complaining witness is a judge? Is the ugly spectacle of judging the judges more repugnant than refusing to subject them to searching judgment? One can almost hear the anxious rejoinder welling up only to be suppressed by awareness of its implication: what if most, or all, of these lawyer contempt citations were found to be unwarranted? What, indeed?

\section{B. Citation and Hearing Procedure}

The Trial Lawyers Report has no provisions governing the procedures for citation and hearing of lawyer contempts, except negative ones:

The judge may exercise this power [of summary punishment] with. out a jury, without making a new record and without referring the matter to another judge. He may do so at any stage of the proceedings without waiting for their conclusion, and he may do

37. Both federal and state law require the presiding judge to support a summary contempt conviction with some record of the incidents in question. In fecleral courts, Rule 42(a) of the Federal Rules of Criminal Procedure provides that: "A criminal con" tempt may be punished summarily if the judge certifies that he saw or heard the conduct constituting the contempt and that it was committed in the actual presence of the court. The order of contempt shall recite the facts and shall be signcd by the judge and entercd of record." The general rule applicable in most states is that "the record must set out the proceedings of the lower court and the facts which support its jurisdiction and constitute the contempt." 17 C.J.S. Contempt \& 122 (1968).

38. See, e.g., Tumey v. Ohio, 273 U.S. 510 (1927). 
so as many times as appears necessary to ensure fair and orderly proceedings. ${ }^{39}$

There is an indirect recognition that jury trial may not be dispensed with where the penalty for contempt exceeds six months imprisonment ${ }^{40}$ but no discussion of other procedural strictures to be observed in cases of such seriousness. For neither summary nor jury-tried proceedings are there proposals concerning the elementary features of fair procedure: notice and particularization of issues; opportunity to prepare and to consider settlement or compromise; assistance of independent counsel for the court and the accused lawyer; procedure for reception of evidence; scope of proofs; opportunity for oral and written argument; requirement of deliberation; making of findings of fact and a statement of the application of law to fact. The Report's single specific admonition is that the trial judge should not postpone hearing the contempt ("allow contempts to accumulate"); its only affirmative details concern punishments. ${ }^{41}$

The ABA Report proposes a procedural scheme that is "summary" only in name. There is an unequivocal notice requirement. No citation for contempt may issue unless "it is clear . . . that disruptive conduct was willfully contemptuous," which incorporates notice into the elements of liability itself, or "the conduct . . . was preceded by a clear warning that the conduct is impermissible and that specified sanctions may be imposed ...." 42 When the judge decides, presumably after reflection, that contempt punishment is warranted, he must "as soon as practicable ... inform the alleged offender of his intention to institute such proceedings." 43 The contempt hearing is to be deferred until after the principal trial, thus allowing time for emotions to subside and also time for preparation, "unless-prompt punishment is imperative." 44 In any event, there must be afforded "at least a summary opportunity to adduce evidence and argument relevant to guilt or punishment." 45

As noted earlier, where the trial judge's conduct may have "contributed" to the contempt, the ABA proposal requires the hearing to be held by another judge. As a practical matter such a referral will entail

39. Trual Lawyers RePORT, Principle V.

40. Id., Principle VI.

41. Id., Principle V, commentary at p. 13, and Principle VI.

42. ABA REPORT, Standard F.2 (emphasis supplied).

43. Id., Standard F.3(b).

44. Id., Standard F.3(a).

45. Id., Standard F.4. 
some specification of the charges, the designation of counsel for the judge and perhaps employment of counsel by the lawyer, the reception of proofs as at an ordinary trial, the establishment of a record, and, where required by ordinary applicable rules of procedure, the making of findings of fact and conclusions of law. If contemplated punishment is to exceed six months imprisonment, a jury trial is also obligatory. ${ }^{40}$

The net result of the ABA proposal is a plenary but expedited hearing procedure for contempts in cases where there was substantial interaction between the trial judge and the alleged offender, which probably means all lawyer contempt cases. Its particulars are thus antipodal to those of the Trial Lawyers Report. The disagreement turns on estimates of the efficacy of summary procedure. Presumably there is no disagreement that summary procedure sacrifices much-calmness of atmosphere, thoroughness of inquiry, fullness of deliberation. The question is whether there are significant offsetting gains.

Real summariness cannot be achieved, as the Trial Lawyers Report points out, unless the trial judge himself hears and decides the contempt citation. Yet, as the Trial Lawyers Report also acknowledges, in such an instance there is still a right of appeal, which in turn makes impossible the summary establishment of final conviction of contempt. Summary procedure can therefore be effective only if: no appeal is taken, which is highly improbable in these matters; or to the extent that summary conviction permits immediate levy of punishment; or because there is deterrent effect from a contempt conviction pro. nounced by the trial judge as distinct from a citation on his part. And the relevant measure of effectiveness is not simply whether a summary conviction enhances the probability of eventual punishment, but whether it enhances the probability that the lawyer will forthwith alter his deportment in the principal trial.

There is not much practical possibility that summary conviction will permit swifter levy of punishment. If the principal trial is over, summary hearing saves little time over a plenary hearing. If the principal trial is still going on, how can service of the sentence commence immediately? If there is an immediate appeal, the lawyer will probably be released during its pendency. Even in absence of an appeal there is no way the trial judge can put the lawyer in jail that is not self-defeating. Suspending the principal trial while the lawyer serves time only delays the proceeding whose expedition is the ultimate aim; having the law.

46. Cheff v. Schnackenberg, 384 U.S. 373,380 (1966). 
yer serve the sentence at night and on weekends leaves him without rest and opportunity for continuing preparation and thereby subjects the principal trial to severe risks of mistrial or eventual reversal; if the lawyer is to start serving his sentence after the principal trial, there is no practical reason why the contempt hearing itself cannot be postponed, nor if postponed why it need be summary.

The utility of summary contempt procedure, if it has any, thus lies in the difference in immediate deterrent effect between a conviction which is provisional because it is appealable, and a citation. But is there a significant difference between them? The distinctive features of a conviction are its technical finality and its presumptive validity, while a citation is only an accusation. But a "final" contempt judgment does not necessarily result in instant subsidence of the conduct in question. After being convicted, the lawyer may persist in his tactics on the theory that he may as well be hanged for a sheep as for a goat and possibly on the theory that perseverance implies honest belief in the propriety of his conduct, a state of mind which reviewing courts usually regard as a mitigating circumstance. An accusation that is to be followed by a hearing before a disinterested judge would seem to have at least as powerful an admonitory effect as a conviction by a judge whom the lawyer sees as a protagonist.

The case for summary procedure in lawyer contempts thus seems marginal at best. Against it is the principle that, in the absence of compelling exigency, no one should be condemned or punished except after an ample hearing before an unbiased tribunal. Against it also is the proposition that the perceived meetness of rules of conduct is partly a function of the perceived fairness of the procedure through which they are enforced.

\section{Trial Procedures}

Neither the Trial Lawyers Report nor the ABA Report goes extensively into the matter of trial procedures in cases likely to engender conflicts between judge and lawyer. Both contain general precepts which are at the same time unexceptionable and only moderately illuminating. One could wish for much more concrete proposals, for example:

The use of daily or at least weekly conferences in chambers between court and counsel to smooth and restore working relationships and to anticipate evidentiary questions and rulings;

The definitive explication of "continuing objection" positions by counsel and "same ruling" decisions by the court to minimize the repetition of irreconcilable differences; 
The requirement of written briefing of major substantive and evidentiary positions, with responsive rulings in limine by the court, so that positions are made as clear as possible.

Suggestions along this line are absent from the $A B A$ Report presumably because such matters are covered elsewhere in the Minimum Standards monographs. ${ }^{47}$ They are absent from the Trial Lawyers Report presumably because they were thought outside its scope. Yet the omissions, which could have been partially overcome by incorporating references to other sources, imply that the technical aspects of conducting a trial have limited relevance to courtroom disruption and contempt of court. Procedural mechanisms of course cannot themselves constrain extreme forms of lawyer misbehavior. But some lawyer misconduct is probably the product of fear or anxiety about the rulings and attitude of the trial judge. To the extent these can be allayed the trial is likely to be less acrimonious. And some lawyer contempts of recent history may have resulted from failure of the trial judge to accord the lawyers the opportunities of responsible participation in management of the trial that are conventional in complicated litigation.

Between them the reports have two proposals on trial procedure that surely merit general implementation. The ABA Report proposes that

the trial judge, whether before a criminal trial or at its beginning, should prescribe and make known the ground rules relating to conduct which the parties, the prosecutor, the defense counsel, the witnesses, and others will be expected to follow in the courtroom ....".48

The Trial Lawyers Report tenders a somewhat similar but much less definite proposal. The desirability of such a procedure inheres not only in the specific notice it affords but also in its manifestation of an attempt to be completely fair.

The other proposal appears only in the Trial Lawyers Report and is that the lawyer has the obligation

to advise any client appearing in a courtroom of the kind of behavior expected and required of him there, and to prevent him, so far as lies within the lawyer's power, from creating disorder or disruption in the courtroom. ${ }^{9}$

47. See ABA Project on Standards for Criminar Justice: The Prosecution function AND THE DEFENSE Function 100 (tentative draft, March 1970).

48. ABA REPORT, Standard A.4.

49. TrLal LaWyers Report, Principle III(d). 
The reach of the duty is not elaborated. It is not stated, for example, what a lawyer is supposed to do if the client persistently misbehaves despite his advice to the contrary. The Manson case in Los Angeles Superior Court presents that problem and suggests that it is no real answer to say the lawyer should resign from the case, for what will his successor do? But if the outer limits of the duty are imprecise the same is not true of its initial form: the lawyer should tell his client to behave himself, and do so with sincerity or at least its verisimilitude.

Of late it has been argued otherwise-that his client's courtroom conduct is none of the lawyer's business. The contention is that the lawyer is but an agent, that the client as principal can have his case presented any way he wants to, and that the agent's responsibility ends with giving the principal advice. More fundamentally, it is suggested that there are cases where the defendant's style is itself on trial and in such cases the defendant has, as it were, a right of affirmative defense.

There is something to this. The client does have certain procedural initiatives which the advocate can neither waive nor exercise on the client's behalf: the right to speak before pronouncement of sentence, ${ }^{50}$ the right to advice on consequences before tendering a guilty plea, the right to be present and to confront witnesses, 52 and perhaps the right to testify against his counsel's advice. ${ }^{53}$ Furthermore, the hippy or yippy defendant has a right to insist that the impartiality by which he is adjudged not depend on changing his life-style pendente lite, just as the poor man should not have to change his clothes nor the black man his skin. It is also no doubt true that judges and prosecutors often confuse déshabillé with disorder and perceive loud mannerisms as literally making noise.

When due allowance is made for all these considerations, however, the fact is that we have witnessed some trials in which the defendants have talked when they should have been silent, moved about when they should have been seated, gesticulated when they should have been in repose. The lawyer's duty to admonish his clients against such misbehavior is sometimes supported by the argument that he has special

50. See, e.g., 24B C.J.S. Criminal Law \$ 1948(1): "[t]he appellate court may also revere [for] failure to accord allocution ...."; and 24 C.J.S. Criminal Law \$ 1688 . See also Rule 32(a), Federal Rules of Criminal Procedure, and Green v. United States, 365 U.S. 301 (1961); Hill v. United States, 368 U.S. 424 (1962).

51. See, e.g., ABA Project of Minduuas Standardos for Crminal Justice, Plens of GuLTY, § 1.4 (tentative draft, Feb. 1967).

52. See Illinois v. Allen, 397 U.S. 337 (1970).

53. See The Prosecumion Function aNd THE Defesse Fusctios, supro note 47, at § 5.2(a) and commentary. 
leverage on them and should use it to help his professional colleague on the bench in keeping order. There is truth in this but also odium, particularly to the members of a generation that is highly and understandably sensitive to manipulation. The lawyer's duty to admonish his clients surely rests on more substantial ground than that as an officer of the court he is also one of its bailiffs.

The duty, it may be suggested, is a component of the lawyer's own role as advocate. The role of advocate is that of spealing to questions of law and fact in a particular kind of forum in accordance with specified opportunities and sequences. It would be quite clear that the lawyer could not play his role if whenever he tried to speak he was ignored, or interrupted or drowned out by a bullhorn. The lawyer's part, however, is not soliloquy but-the pun is irresistible-a trialogue, a series of ordered exchanges with the judge and opposing counsel. If the judge and opposing counsel cannot speak without disruption or hindrance, then the lawyer's appearances and cues are lost or disordered and at some point his role and reason for being there simply collapse. If the advocate does not contribute to sustaining these forensic requirements, he has to that extent abdicated his role and literally has no place in the performance. And if he does not believe in his role and cannot live it, he should seek another calling, just as an atheist should leave the priesthood.

The same, of course, goes for the judge and the prosecutor. To some who observed the "Chicago Eight" trial, one of the appalling things was the noisome patter of witticism and jokes by Judge Hoffman. It is conceivable that if he had consistently avoided playing it like at minstrel show, the defendants might not have played it like a circus.

\section{Pre-Trial Arrangements}

Aside from their "ground rule" recommendations, neither report deals much with pre-trial arrangements, evidently again because their defined scope excludes such matters. The ABA Report suggests special arrangements for seating news media representatives. The Trial Law. yers Report recommends that the trial judge not only rule impartially on challenges addressed to him but also that he "disqualify himself without challenge if he is biased or plausibly may be suspected of bias." 54 These needful and commendable suggestions call to mind others which are not made: selection of spectators by lot and assign.

54. TRIAL Lawyers Reporr, Principle IV(a). 
ment of their seating by number; pre-screening of venireman to eliminate the clearly challengeable and to establish a pool of highly eligibles from which to begin jury selection; assignment of an associate judge to help monitor the trial and to confer with the principal judge on rulings; and similar unorthodoxies. ${ }^{65}$ However, both reports, as noted, speak particularly to the matter of pro hac vice admissions of non-local attorneys. This recommendation implies that the most pertinent preventives of trial disruption concern the attorney, especially the defense attorney in criminal cases. This may be true as far as it goes, but it opens up more searching questions.

On the matter of pro hac vice admissions, both Reports would authorize the trial court to grant temporary admission of a non-local attorney only on the condition that local counsel be associated in such an active way as to be ready to take over if principal counsel "is re. moved" (Trial Lawyers Report) or "becomes unable to or unwilling to perform his duties" (ABA Report). Beyond this, the ABA Report authorizes the trial judge to deny pro hac vice admission to a lawyer who "has been held in contempt of court or otherwise formally disciplined for courtroom misconduct, or has disciplinary proceedings for courtroom misconduct pending against him in any jurisdiction," while the Trial Lawyers recommendation would authorize denial of admission to a lawyer who has "willfully engaged in disorderly or disruptive tactics in any other court" whether or not he has been convicted of contempt or is the subject of a pending contempt proceeding. ${ }^{.7}$ These are novel and restrictive proposals, even though ones whose inspiration is understandable. The out-of-state attorney does not know the local forensic conventions, judicial idiosyncracies and modes of courtroom discourse, and his ignorance can be the cause of unintended tensions. The ordinary intonation of some city lawyers, for instance, sounds to the provincial ear like the prefiguration of physical violence. A less delicate point is that one of the chief inhibitions on lawyer aggressiveness is the knowledge that he will have to be in court for another cause on another day before the same judge, a constraint to which the "national" lawyer is not subject. An even less delicate point is that tightening pro hac vice admission may inhibit the ease with which name-recognizable lawyers are able to tender their services to defendants who lack established relations as to counsel.

55. Cf. Handbook of Recommended Procedures for the Trial of Protracted Cases, 25 F.R.D. 351 (1960).

56. ABA REPORT, Standard D.2(a).

57. TriaI LAwYers REFort, Principle $X$. 
The proposals are nevertheless severe in some of their potential applications. Read literally, they mean that a lawyer once held in contempt for disorder is for all time excludable from all courts except those to which he has been permanently admitted; a single jurisdiction can thereby give a lawyer a kind of negative license to practice outside his home state. Read literally once more, they mean that a lawyer who has never been charged with such conduct can be denied pro hac vice admission unless there is a local lawyer who is willing to take the case on what amounts to a standby basis and whom the client is willing to accept as alternative counsel; this makes admission dependent on arrangements that are awkward and perhaps repugnant both to local counsel and to the client. In addition, they give the trial judge a potent sanction against the attorney admitted pro hac vice which is not available against a locally admitted attorney - the power to remove him from the case without the cost of a mistrial. That may be more authority than some trial judges ought to have.

A more searching question that comes to mind in pondering the pro hac vice proposals is this: would we apply the same proscription to a prosecutor found guilty of grossly unfair tactics, or a trial judge who had been reversed for indulging them?58 The irritating character of the question emphasizes its pertinence.

\section{Courtroom Order in the Political Trial}

The immediate inspiration of the recommendations by the Trial Lawyers and the ABA was a "political" trial. Their appositeness to that kind of dispute requires brief further analysis.

A political trial is one in which the defendants-they are usually plural-are tried for conduct that is interpreted by them and by the community at large as a challenge to the legitimacy of the political order. The conduct may be pure challenge, such as advocating overthrow of the government, or a challenge manifested in conduct that is independently unlawful, such as a riot or sit-in. When uttered, the challenge constitutes an appeal to some public or other for support. The subsequent trial is of itself conclusive evidence that the challenge failed, for if it succeeded the defendants would have been vindicated and not face prosecution.

From the viewpoint of the challenged authority, the issues in a

58. Cf. The Prosecurion Funcrion and tie Defense Funcrion, supra note 47, at $\S \S 3.11$ and 5.6 . 
political trial are defined by its positive law: whether the challenge enjoys the immunity afforded to free speech; whether all defendants were accomplices to the illegal elements of the enterprise; whether, regarding challenges expressed as action, there were excuses or justifications such as antecedent illegal action by officials; and so on. From the veiwpoint of the defendants, however, these are only some of the issues. If the defendants desire exoneration, their surest recourse is not legal defense but public contrition, for in that event there would usually be no trial. A political case that goes to trial is one in which the defendants have counterclaims.

The counterclaims in a political trial are based on a maddening combination of transcendental political or ethical issues and procedural technicality. One counterclaim is that the regime-all of it or the part directly involved in the altercation-is illegitimate according to some theory of political justice so that the actions of its officials are not clothed with legal authority and therefore amount to naked coercion. A subsidiary count is that the court trying the case is part of the illegal system and that its proceeding is a juridical pretension and a farce, as indeed it is if the premise is accepted.

The second counterclaim is that the court will not try the case with proper observance of its own legal procedure. This claim depends on technical and sometimes hypertechnical interpretation of procedural law and may involve tactics which seek to make it a self-fulfilling prophecy. Like the first counterclaim, it asserts that the court is not really a court. But the second counterclaim is supported by an argument which is diametrically opposite to that supporting the first counterclaim. The argument is that according to the tribunal's own law, the tribunal is not functioning as one.

A political trial thus involves two and perhaps three concurrent proceedings. In the "straight" one, the prosecutor is the accuser, the defendants are the accused and the judge and jury are arbiters. In the trial of defendants' first counterclaim, the defendants are the accusers, the prosecutor and the judge (and sometimes the jury) are the accused, and the arbiter is indefinitely the jury (hence the struggles at voir dire), the defendants' circle of sympathizers, the world at large, or history. The alignment of the parties is the same in the defendants' second counterclaim except that the arbiter is the appellate courts.

The confusion over the participants' position is confounded by evidentiary problems. The evidence for the government in a political trial consists largely of the defendants' utterances-writings, speeches, discussions. These are what actuated the prosecution in the first place 
and what constitute the legal basis for regarding the defendants' con. duct as peculiarly wrongful. Hence, in putting on its case the prosecu. tion inevitably rebroadcasts the defendants' challenge of the regime and thus introduces evidence which defendants regard as relevant to their first counterclaim, that the tribunal is illegitimate. Defining the proper scope of these proofs involves continual rulings that are subject to the claim of prejudicial error. Sometimes the defendants seek to introduce even fuller accounts of their utterances. If this effort is successful, it buttresses their first counterclaim; if it is unsuccessful, it buttresses the contention that the court is not trying the case fairly.

The proceeding as a whole is thus suffused with ambiguity: proofs consisting of speeches, which bear simultaneously on issues that have been pleaded and others that have not been, which are punctuated by evidentiary and procedural issues laden with double or triple meaning, which are advanced by participants who are intermittently forgetful that the conflict encompasses the agenda and their respective roles. Rules that clarify the official roles and responsibilities in the hearing of such a case can help define the issues in the underlying struggle over whether the official version of the proceedings shall prevail. Reaffirma. tion of the contempt power confirms the consequences if the established order does prevail. The established order, however, by its own terms cannot win the struggle by the threatening mechanisms of legal prescription and penal sanction. It can win only through steadfast and unpretentious fulfillment of official roles, especially that of the judge. In the emphasis it tries to give this aspect of the problem, the $A B A$ Report may have made a particularly important contribution. At the same time, it is well to recognize that the struggles represented in political trials will not disappear until fundamental political dissension also disappears. That day may be less welcome than many might think. 